\title{
SINGLE LAYER I.T.
}

\section{A collective celebration.}

\section{BY WILLIAM R. D. WOOD}

$\mathrm{T}$ he Waterford ball blazed into life and began its descent.

\section{Sixty seconds.}

The cheer and following swell of voices resonated in her temples and the sphenoid deep behind her nose. Shana was dizzy. The press of the crowd in Times Square was almost enough to hold the freezing New York night at bay. She closed the connection to the server back at the office and swiped the tablet to sleep.

Camera strobes fired from every direction. Family and long-time friends commemorated once-in-a-lifetime trips to the Big Apple. The hajj of the West. The air hung heavy with alcohol and musk, and she was reminded that many around her hadn't known each other a few hours ago. So many full of impure thoughts and desires. Celebrating and oblivious to those less fortunate.

Oblivious to those suffering pilgrims among them even now. Oblivious to her. Those less connected in a world population that had never been more connected.

Above, light rippled across the ball, overlaid patterns interspersed with bursts of colour. The promos had touted this year's theme for weeks, echoed tonight by every feed, private and commercial. The message was simple. New Year. New York. New World. A global culture that simultaneously embraced unity and individuality.

The promise of progress and understanding had never burned brighter, said all the newsfeeds. First North America, then the world.

They were right, of course.

Fifty seconds.

Shana sneezed and wiped her nose. No one noticed. Ignorant of the contagion waiting patiently inside her. She was just another warm body, a drop of water in a churning sea. Her joints ached as the crowd swayed. Her lungs stung from the chill as she shared the breath of others and they shared hers. Her phone buzzed in her pocket. The familiar pattern of her fosters. They were proud but they would be prouder still.

Her eyes burned and her vision swam. She shuddered as the tiny vibration switched on inside her skull. Just like the test runs. The emitter went live right on time. Information and biology; blended, engineered.

A twenty-something frat-boy groped her as he and two buddies shouldered their way past. His drunken gaze met hers and he

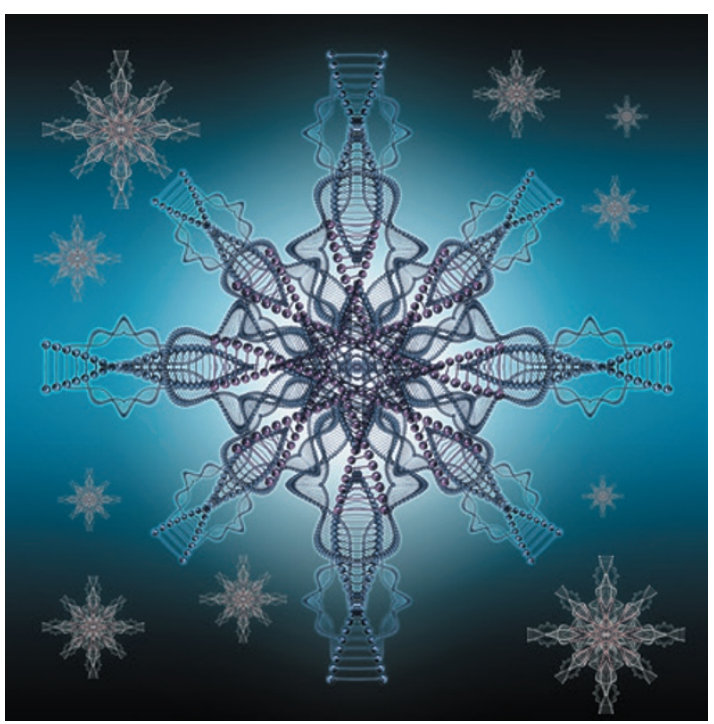

Times Square! Grand Central, LaGuardia, the subways and every post office, park 욱 and public place within driving range. And she'd touched everything.

Twenty.

Lights throbbed, the voices around her a palpable force, threatening to buoy her from the ground. She coughed and dozens around her coughed as well, the reaction spreading outwards like a ripple in a lake of humanity.

Shana laughed. Experts had long remarked on the eerie structural similarity between a strand of DNA and a helical dipole antenna.

Ten.

It was as if nature had intended humanity to be a linked community from the very beginning. Higher order in the entropic background soup. People should be more than an hour, or a minute or a

shrugged, taking her picture and swiping it off to who knew where - his blog, a newsfeed, one of a billion sites.

Social networking. She smiled. Social pluria would finally be the promised but never truly delivered social media.

Forty seconds.

Winking at him just as he disappeared into the throng, she revelled in his split second of confusion. She'd not be sad to see an end to uninformed selfishness. His lack of connection to her and the countless people like her. The ignored. The alone. Hed know her and she, him.

People pulsed around her.

Displays as big as houses counted down from the towers, some giving the impression that their digits were raining down into the crowd. Scented vapours and smoke from something distinctly illegal tickled her nose and she sneezed. The thunder of voices surged and faded in waves. Her chest thrummed with each word as people joined together, counting in one voice. More and more in sync.

Every penny her fosters had spent sending her to school was worth more with each passing second.

Thirty.

Shana rubbed the bump behind her left ear where she'd administered the injection. She'd done the initial testing on herself. The engineered strains had done the rest. These $\rightarrow$ NATURE.COM

Follow Futures: @ @ NatureFutures $f$ go.nature.com $/ \mathrm{mtoodm}$ past few weeks she'd spent spreading the infection with her pamphlets. Don't Miss New Year's Eve in second in one another's day. Relationships were grander than an excuse to shove one's genetic material into another.

People staggered around her, struggling to process the sudden flood of information. That was to be expected. The disparity must be confusing.

The roar of voices faded.

Never again would a little girl watch her parents waste away without someone to hold her hand.

Five.

The crystal ball dropped its final inches as particles 3 million times smaller swarmed across blood-brain barriers. Mostly just NYC today. But this gift would spread, unstoppable. She'd been one of lucky ones but there were many more.

Countless more.

Four.

After a few days, no one would want to. Right now there were shouts for help echoed among those yet to be infected. Yet to be connected. But that would pass. Never again would a child depend on pedestrians for food.

Three.

A collective gasp rose from Times Square. Never again would anyone long for a single word.

Two.

Never again. Because. We. Are.

One. -

William R. D. Wood writes speculative fiction from a secret lair in the mountains of Virginia. You can find him online at www.williamrdwood.com. 